\title{
CHARACTERISTICS OF POWER OF ATTORNEY FOR MORTGAGE RIGHTS ON COLLATERAL LAW SYSTEM IN INDONESIA
}

\author{
Agung Cahyo Kuncoro* \\ Herowati Poesoko** \\ Dyah Ochtorina Susanti*** \\ Aries Harianto $* * * *$ \\ * Researcher, doctoral students of Faculty of Law, University of Jember \\ ** Professor at the Faculty of Law, University of Jember, in the field of Civil Law \\ ***doctor at the Faculty of Law, University of Jember, in the field of Civil Law \\ **** doctor at the Faculty of Law, University of Jember, in the field of Labor law
}

\begin{abstract}
There are two ways in executing mortgage rights, i.e., first, transferring the mortgage right by issuing mortgage deed (APHT) by the Land Deed Official (the PPAT) by making guaranteed debt agreement initially. Second, registration at the Land Office as the issuance of mortgage rights. Provision of the General Explanation of paragraph 7 (seven) of the Act Number 4 of 1996 on Mortgage rights on Land and Land-Related Objects, referred to UUHT, stated that "in transferring the mortgage, the lender should attend before the PPAT, or appointing other party to present on his behalf with the Power of Attorney to charge for Mortgage Rights (SKMHT) in form of an authentic deed." By this provision, the SKMHT is made based on a certain circumstance (optional). Inversely, the Article 15 Paragraph (2), Paragraph (3), Paragraph (4) of the UUHT regulates the period of SKMHT, and Article 15 Paragraph (5) of the UUHT states that SKMHT is used to guarantee a certain type of loan. It is supported by the ratification of PMA No. 4 of 1996 concerning Determination of the Deadline for the Use of Power of Attorney to charge for Mortgage rights to Guarantee Certain Credit Settlement, which are then replaced with PMA No. 22 of 2017 concerning Determination of the Deadline for the Use of Power of Attorney to charge for Mortgage rights to Guarantee Certain Credit Settlement. Under the provision, the SKMHT is used as a quasi-collateral. Thus, a legal reform of the SKMHT is important to realize the legal objectives, namely, legal justice, certainty and expediency, both for the community and stakeholders.
\end{abstract}

Keywords: The SKMHT, Mortgage Rights.

DOI: $10.7176 / \mathrm{JLPG} / 87-22$

Publication date:July $31^{\text {st }} 2019$

\section{Introduction}

There are some agreements made for engagements summarized in form of right and obligation clauses to be obeyed by each involving parties. Any denial on the agreements by one party may harm another. To grant this circumstance, a collateral is provided to facilitate the settlement of obligations arising from the agreement. The Book II of B.W. stated 2 (two) collateral institutions, namely pawning and mortgage institutions. Pawnshop works for movable objects which develop to be fiduciary institution ${ }^{1}$, While the mortgage institution works for immovable objects.

The establishment of Act Number 5 of 1960 concerning Basic Agrarian Principles (hereinafter referred to as UUPA) concluded that all matters relating to land are regulated in Act Number 4 of 1996 concerning the Mortgage rights and Land Related Objects (hereinafter referred to as UUHT). ${ }^{2}$ Article 1 Number (1) of UUHT explains that mortgages are imposed on land as referred to the Act Number 5 of 1960 concerning Basic Agrarian Principles, with or without the land related object, for repayment of certain debt, which prioritize certain creditor to other creditors. There are several privileges of mortgages, i.e., giving a priority or overtaking position to the holder; Always follow whoever hand the objects; fulfill the principle of specialty and publicity so that it can bind third parties and provide legal certainty to interested parties; and guarantee an easy and certain execution.

\footnotetext{
${ }^{1}$ See and read Article 1 number 1 of Act Number 42 of 1999 concerning Fiduciary Guarantees, Fiduciary is the transfer of ownership rights of an object on the basis of trust with one condition that the objects whose ownership rights are transferred is still under the owner s supervision

${ }^{2}$ See and read Article 51 of Act Number 5 of 1960 concerning Basic Agrarian Principles
} 
Article 1162 B.W. explained that a mortgage is a material right for immovable objects as a replacement for repayment of an agreement. According to Subekti there are at least 4 (four) documents in the provision of credit with mortgage collateral, namely: the actual credit agreement which can be held with a deed under the hand; Power of attorney to execute an authentic mortgage; The an authentic mortgage application; the mortgage certificates issued by cadaster (Dir. Dir. Agrarian). The assignment of mortgages is carried out in 2 (two) ways, namely: first, transferring the mortgage right by issuing mortgage deed (APHT) by the Land Deed Mortgage (the PPAT) by making guaranteed debt agreement initially. Second, registration at the Land Office as the issuance of mortgage. The general explanation of paragraph 7 (seven) of UUHT states that if the creditor is unable to present, there should be other party appointed to act on his behalf by giving an authentic Power of Attorney (SKMHT) made before a Notary or PPAT.

Pawning and mortgage institutions has its own Power of Attorney form in the implementation of the collateral, the SKMHT belong to pawning institution, while the SKMH belongs to mortgage institution. The SKMH is a part of mortgage document, while the SKMHT is optionally made, because principally the mortgage rights should be handed by the owner himself. It is based on the general principle that legal action should be carried out by the people having interest. ${ }^{1}$ Likewise, the explanation of Article 15 Paragraph (1) UUHT stated that "...the use of Power of Attorney, urgently necessary, for charging mortgage right is allowed only when the interest party cannot attend before the PPAT". The term "urgently necessary" has value of vague norm which show its uncertainty.

Additionally, it is interesting to examine the nature and characteristics of the SKMHT, based on the epistemology and systematic formulation in the collateral law. If the assignment of mortgage rights is carried out by the interested parties, it will be done through the APHT, but if the transaction is processed by the third parties, it should be done based on the SKMHT. The concept is confusing due to the action of "giving" is based on the attorney using the term "to impose". These concept definitely have different juridical consequences, considering that law is the science of meaning (sui generis). ${ }^{2}$

Referring to the concept of authority, principally to grant power of attorney is a unilateral act given through unilateral legal actions, ${ }^{3}$ which in its use, it will become an agreement. To grant power of attorney is done by granting the power to certain people himself. In the past, the SKMH is made as an unilateral statement. Because the SKMH is given for the bank interest as a creditor, the power of attorney is granted to a particular bank. Unlike the UUHT, though the SKMHT should be made in form of non-unilateral agreement, referring the required form, it should be in form of agreement. Therefore, the validity of granting the mortgage rights depends on the legality of the agreements.

Regarding the above description, the general provision stating that the validity of a power of attorney does not depend on the validity of the repayment agreement, meaning that the power of attorney is an independent act that does not need any title for its implementation.

The above elaboration of the SKMHT concept shows that it is part of Collateral Law or part of power of attorney in general. Therefore it needs to find most proper meaning of the SKMHT to provide legal certainty for stakeholder. In addition, by knowing the meaning of SKMHT in a collateral legal system, it can also be determined in a legal system which based on the rules and principles of the law that apply appropriately and certainly.

Furthermore, the presence of the SKMHT has a very important role for the life of the country's economy. Sociologically, the banking credit cannot be done without the SKMHT under certain conditions including: take over, home ownership loans, credit with buying and selling process, credit with a certificate, cancellation process, title transfer process, etc.

In fact, the presence of the SKMHT is not followed by the provision of strong legal force concerning the SKMHT itself, so its existence in the collateral legal system does not provide legal protection for creditors and / or debtors who will ultimately harm the sense of justice in the community. Designing and forming laws that can be accepted by the wider community is a difficult job. This difficulty lies in the fact that the activities of

\footnotetext{
${ }^{1}$ J. Satrio, Hukum Jaminan, Hak Jaminan, Hak Tanggungan Buku 2, (Bandung: Citra Aditya Bakti, 1998), p. 165.

${ }^{2}$ Philipus M. Hadjon dan Tatiek Sri Djatminiati, Argumentasi Hukum, Sixth edition, (Yogyakarta: Gadjah Mada University, 2014), p. 1

${ }^{3}$ J. Satrio, Op. Cit., p. 176.
} 
establishing legislation are a form of communication between institutions that establishes i.e., the holder of legislative power with the people in a country, ${ }^{1}$, and considering that legislative products are never perfect.

Therefore, one of legal sources used to provide legal certainty is jurisprudence .The followings are jurisprudences related to the SKMHT:

1. Decree of the Supreme Court Number 2006K / PDT / 2011 Jo. Number 251 / PDT / 2010 / PT.DKI Jo. Number 349 / Pdt.G / 2008 / PN.Jkt.Bar, which is in the legal consideration (Ratio Decidendi) of the Panel of Judges in the case of cassation, namely: SKMHT No. 8 November 5, 2001 did not fulfill the element of Article 15 UUHT because the SKMHT was signed by a person claiming to be an applicant where the applicant did not sign the SKMHT. Therefore, the SKMHT is legally null and void by law. So that any set of engagement based on null and void legal defects is null and void by law. The Judge's decision. in this case is: Accepting a request for applicant's cassation;

2. Decision of the Muara Bulian District Court Number 01 / Pdt.G / 2015 / PN.Mbn dated November 10, 2015. In the legal considerations the Panel of Judges considers that Defendant I through Defendant II has made the certificate of ownership no. 76 as collateral to the defendant V as No. APHT object. 0755 / XI / 2010 based on SKMHT No. 105 dated 29 October 2010. This is clearly detrimental to the Plaintiff as the holder of the Binding of the Deed of Sale and Purchase of land used as objects in the APHT on the basis of SKMHT. Meanwhile, the existence of SKMHT, APHT, and Credit Agreement Letter made after the binding of the Sale and Purchase Deed made in the plaintiff is unknown to the plaintiff, so the SKMHT as the basis for making APHT does not meet the objective requirements of Article 1320 BW. The Panel of Judges concluded that the SKMHT, the APHT and the Credit Agreement were null and void by law. The Panel of Judges in its decision granted the plaintiff's claim.

The rationales in this study are a). The most appropriate concept regarding Power of Attorney for Mortgage; b). Position of Power of Attorney for Mortgage Rights in a collateral legal system; c. The basis for the establishment of a Power of Attorney for Mortgage; d). The function of the Power of Attorney for Mortgage in a collateral legal system.

Based on the background and legal issues, several legal issues were found as follows:

1. What is the nature of the Power of Attorney for Mortgage in the collateral legal system in Indonesia?

2. What is the ratio legislation regulating the Power of Attorney for Mortgage in the collateral legal system in Indonesia?

3. How is the future legal construction of a Power of Attorney for Mortgage in the collateral legal system in Indonesia?

\section{Research Method}

This study is normative juridical which focused on examining the application of rules or norms in the applicable positive law. ${ }^{2}$ The approaches used are statute approach, conceptual approach, historical approach, comparative approach and case approach.

\section{Results and Discussion}

The results and discussion will analyze some of the problems above mentioned, as follows:

\subsection{The Nature of Power of Attorney for Mortgage in the Collateral Legal System in Indonesia}

1. Characteristics of Power of Attorney for Mortgage in the Agreement Law

${ }^{1}$ Okky Ditya Argo Putra, Prinsip Prinsip Hukum Jaminan dalam Undang-Undang Nomor 4 Tahun 1996 tentang Hak Tanggungan Atas Tanah beserta Benda-benda yang Berkaitan dengan Tanah, Jurnal Reportorium first edition, January-July, 2014, p. 52

${ }^{2}$ Peter Mahmud Marzuki, Penelitian Hukum, (Jakarta: Kencana Prenada, 2010), p. 27. 
Before the establishment of UUPA, the material rights that guarantee repayment of an agreement on immovable property is a hypothec. ${ }^{1}$ Article 1168 B.W. states that a mortgage should be held by a person who has the authority to transfer goods charged with a hypothec. This authority can be obtained by granting the authority to execute a hypothec in the form of the SKMH. ${ }^{2}$ After the enactment of the UUPA, all land-related subjects are regulated in the UUHT. ${ }^{3}$ Purawahid Patrik and Kashadi said that the pawning institution of mortgage rights is a strong institution having a position that is prioritized for the holder (droit de preference) and following the object of mortgage rights in the hands of the object holder (droit de suite). ${ }^{4}$ Article 1 Number 1 of the UUHT defines Mortgage Rights as collateral rights imposed on land rights, with or without other objects related to the loans, for repayment of certain debts to other creditors. Referring these definitions, there is a division of pawning institutions for immovable objects. This certainly will cause a shift in the regulation of collateral rights imposed on land rights.

The UUHT explains that in granting mortgages, the provider of the principal/power grantor must be present before PPAT. and should appoint another party as on his behalf to attend with SKMHT in the form of an authentic deed. The SKMH is known in the mortgage collateral institution, while the SKMHT is related to mortgage rights collateral institution. The explanation of Article 15 Paragraph (1) The UUHT states that principally, the imposition mortgage Rights must be carried out by the giver of the right. But, if he cannot attend before the PPAT, he is allowed to use SKMHT. In line with that, the Power of Attorney must be given directly by the person, and should fulfill the requirements regarding the contents stipulated in this paragraph. The failure to fulfill this requirement caused SKMHT void by law, which means it cannot be used as the basis for making the APHT. ${ }^{5}$

The elaboration explicitly states that the SKMHT is used as the basis for making the APHT. However, the inconsistency of the SKMHT used as the basis for making the APHT consisted in Article 15 Paragraph (5) of the UUHT stating that the provisions referred to in paragraph (3) and paragraph (4) is not applicable in SKMHT given to guarantee certain loans stipulated in regulations. Referring the explanation of Article 15 Paragraph (5) of the UUHT that in the development, considering the low economic group, the provision of certain loans stipulated by the government such as program loans, small loans, housing loans and other similar loans, the SKMHT expiration date as referred to in paragraph (3) and paragraph (4) is not applicable. Based on these provisions there seems to be a dualism of the SKMHT function. On the one hand, the SKMHT functions as the basis for making the APHT, and on the other hand it is used to guarantee certain loans as confirmed by Minister of Agrarian and Head of National Land Agency Number 22 of 2017 concerning Determination of Deadline for Use of Power of Attorney for Specific Credit (PMA Determination of the Deadline for the Use of SKMHT to Guarantee Repayment of Certain Loans).

Referring to the concept of power in B.W. as stipulated in Article 1792 B.W. explained that the granting of power of attorney is an agreement that contains the granting of power to someone else who receives it to implement something on behalf of the person granting the power. Article 1793 B.W. mentioned that the Power of Attorney are in form of a general deed, a private deed, a letter, oral, secretly, special and general words. Article 1796 B.W. states that the authorized person may not do anything that exceeds his power. The end of power according to Article 1813 B.W. i.e. the withdrawal of power from the recipient of the power of attorney; notification of termination of power by the authorized person; death, custody or bankruptcy, both the power of attorney and the recipient of the power of attorney. In addition, the principal (one granting the power) may withdraw his power if he is willing and forces the power holder to return the power under certain reasons. ${ }^{6}$ In principle, authorization can be seen from the understanding of granting power; form of power and the occurrence of power; obligation of the principal and attorney; and the end of authorization.

Principally, the SKMHT has been regulated in Article 15 of UUHT. Alwesius said that the SKMHT is a letter or deed containing the power of attorney given by the grantor to the attorney to act on his behalf to grant the right to the creditor on the land (collateral) owned by the principal. ${ }^{7}$ The SKMHT as the basis for making APHT, in its process should consider the authority possessed by the principal as the right holder. The extent to which the

\footnotetext{
${ }^{1}$ See and read article 1162 Burgelijk Wetbook.

${ }^{2}$ See and read article 1169 Burgelijk Wetbook.

${ }^{3}$ See and read Article 51 of Act Number 5 of 1960 concerning Basic Agrarian Principles

${ }_{4}^{4}$ Purawahid Patrik and Kashadi, Hukum Jaminan, (Semarang: Badan Penerbit Univ. Diponegoro, 2009), p. 109.

${ }^{5}$ See and read the Explanation of Article 15 Paragraph (1) of Act Number 4 of 1996 concerning the Mortgage Rights over Land and Land Related Objects.

${ }^{6}$ See and read article 1814 Burgelijk Wetbook

${ }^{7}$ Made Oka Cahyadi Wiguna, SKMHT dan Pengaruhnya Terhadap Pemenuhan Asas Publisitas dalam Proses Pemberian Hak Tanggungan, Paper of Universitas Pendidikan Nasional, Denpasar, 2015. P. 3.
} 
principal has the right to act on the object of the mortgage, in the land registration system is known as the principle of nemo pus yuris which states that basically every person can only be justified in transferring his rights, he is not allowed to transfer his rights which does not belong to him, therefore the SKMHT should be an authentic deed.

Commonly, power entitled with the SKMHT, which is regulated in Article 15 UUHT which consists of 6 paragraphs containing general provisions, conditions for making SKMHT, the nature of SKMHT, the period and legal consequences. The SKMHT in principle does not contain power for other legal actions; does not contain the power of substitution; absolute power; for one imposition; limited applicability.

The authentic requirement of the SKMHT should be based on the principle of providing protection to the giver of the right of any reckless acts. Because the act of granting the SKMHT have enormous consequences, i.e., to eliminate the rights to the guaranteed land. ${ }^{1}$ The implementation of mortgages charges carried out by the attorney based on the SKMHT given by the attorney based on the SKMHT given by the principal, which has consequences on the validity of the implementation of mortgages provisions that depend on the validity of the SKMHT.

The validity of a power of attorney does not depend on the validity of the agreement for the implementation of power of attorney. ${ }^{2}$ It means that if the agreement is not valid, it does not affect the validity of power of attorney. ${ }^{3}$ Satrio stated that to grant power of attorney is an independent legal act. ${ }^{4}$ Considering this fact, if the power of attorney is an independent legal act, then the form and content of the SKMHT concerning the authority relating to the charging of mortgages should be made by the authorizing party or made by both parties (the attorney and the principal). In fact, the Regulation of the State Minister / Head of the National Land Agency Number 3 of 1996 concerning the Forms of SKMHT, APHT, and Certificate of Mortgage Rights determines the form of the SKMHT blank.

\section{Productive Counter of Power of Attorney for Mortgage Rights in the Collateral Law}

The Elucidation of Article 15 Paragraph (1) and Article 15 Paragraph (5) of the UUHT that the determination of the duration of the SKMHT has resulted in inefficiencies in the collateral law. As long as new creditors is at the stage of holding the SKMHT, there are some risks that must be borne by the creditor, i.e., does not obtain priority position. It is to avoid speculation and manipulation, and the misuse of one plot of land to guarantee some credit that exceeds the land value. Likewise, the public interest requires that the use of right should be restricted, by issuing a forcing law.

Regarding the provisions, interpretation, and explanation of the UUHT, It shows that lawmakers want to limit the use of power to charge for mortgages, making the mortgage rights become an obligation. However, this change shows peculiarity that it then should determine the period of the SKMHT validity. The provision of the SKMHT expiry mentioned in Article 2 of PMNA/ Head of BPN No. 22/2017 explaining that the SKMHT is valid until the main agreement ends. In other words, this clause implicate that there is no certain expiry date regarding the validity of the SKMHT, by the andante sentence "until the main agreement ends" indicates that the SKMHT is used as a collateral for credit.

Based on the above regulation, it seems that UUHT does not want the execution of mortgages to end only to the extent of authorization in the form of the SKMHT. The limitation of the SKMHT validity bring some consequences that if it does not follow the regulation of the implementation, the SKMHT will be null and void by law based on the provision of article 15 paragraph 6 of UUHT, even though the expiration period has been stipulated, it will be possible to make a new SKMHT and or extension of the SKMHT.

The permit for republishing the SKMHT is a form of protection provided for the benefit of creditors and debtors for the implementation of charging for mortgage rights. However, on the other hand the concession is actually a form of inefficiency in existing regulations, so that it can create a gap for the misuse of the period. Basically, even though the time limit has been set, a new SKMHT is applicable.

As previously explained, the existence of the SKMHT actually aims to minimize fraud and change the existing process on the power of attorney used as an instrument to delay the imposition of mortgage rights on collateral.

\footnotetext{
${ }^{1}$ J. Satrio, Op. Cit., p. 168

${ }^{2}$ Ibid.

${ }^{3}$ Ibid. P. 170.

${ }^{4}$ Ibid.
} 
If the legal gap for the issuance of SKMHT has met its due date, it is one form of regulation inefficiency relating to the intended period of time.

Furthermore, form of SKMHT inefficiency is also stipulated in PMA Number 22 of 2017 concerning the Deadline of Power of Attorney to charge for mortgage to guarantee repayment of certain credits, in principle, the SKMHT is applicable for credit agreement for repayment certain loans, i.e., the divisions for Micro Small and Medium Enterprises (MSME) loans, and Individuals, House Ownership / houses of $200 \mathrm{M}^{2}$ area, ownership of useable lots with an area of $54 \mathrm{~m}^{2}$ to $72 \mathrm{~m} 2$, as well as other productive loans below Rp. 200,000,000,- (two hundred million rupiah). The SKMHT can be valid as long as the ongoing credit agreement adding to the long list of inefficiencies mentioned above.

The implementation of the SKMHT also requires funding to issue SKMHT deeds as mandated in the provisions of Article 15 of UUHT which states that SKMHT must be made with an authentic certificate include the validity period based on Article 15 paragraph (3) and (4), as follows :

Paragraph (3): SKMHT concerning registered land rights must be followed by the granting of mortgage rights no later than 1 (one) month after being granted.

Paragraph (4): SKMHT concerning unregistered land rights must be followed by APHT no later than 3 (three) months after being granted.

Therefore, regarding the above elaboration, the issuance of SKMHT can be done several times due to any obstacles in the engagement process, solving, reversing the name, etc., so that the issuance needs higher cost which will be granted the SKMHT. This fact absolutely harm the senses of justice for small creditors highly depend on the Bank credits.

\subsection{Ratio Legis of Power of Attorney for Mortgage Rights in the Indonesian Collateral Legal System}

1. Power of Attorney of Mortgage as a Business Breakthrough of Land Rights.

The business world enhancement requires more dynamic law to accommodate legal needs in its activities. The greater the flow of business capital to offset business activities effects business actors to avoid the dependence on third party capital. Banking has a significant role in providing capital for business activities. It is the foundation of the development of a country so that the its existence becomes an indicators of the political development of a nation. On the other hand, it is a country's pillar that supports all economic activities and development in the country. To maintain the stability of the banking industry can be started from maintaining credit stability (performing loans), thus the circulation of funds in the banking sector can run well.

Besides that, the huge capital needs cannot merely be guaranteed by a reliance, as the credit process requirements. Banks need to apply the prudential principle known as $5 \mathrm{C}$ (the fives $\mathrm{C}$ ), the most important in the application of precautionary principle is the collateral. In this case, the immovable object, especially land, is the most demanded collateral. The increasing of people's need and the less collaterals they own rises new problem in the process of credit distribution. To balance the development of capital flow, the credit distribution should be running faster.

The obstacles faced in the implementation of collateral, especially land, caused by the absence of collateral related to some factors including certificates making process, buying and selling process, solving process, title transfer, and even taking over. In fact, the land cannot be used as collateral because of the process referred that hinder the execution of mortgage rights.

The credit activities must be carried out continuously to maintain banking stability, capital flows and the implementation of national development, although problems may always occur. In regards, the SKMHT exists as part of the collateral activity, which can provide legal certainty in the implementation of credit transactions with imperfect collateral condition. The perfection of the assurance is that the ability to grant mortgage rights.

The SKMHT is used as an agreement between the process of credit distribution and the granting of mortgage rights. It makes the SKMHT act as a connector between two related legal activities which cannot be done simultaneously. The emergence of this power of attorney is specifically regulated in which the existence cannot be replaced with other types of power. Regarding the provision of Article 15 of the UUHT, referring to the irreplaceable SKMHT, it deserves special position in the collateral legal system as a golden bridge. 
To analogize the SKMHT as a golden bridge is not a form of exaggeration because without its existence, the credit distribution will be difficult moreover when the collateral is still imperfect. Thus, the procedure of credit distribution should be waiting for the completion of collateral process that needs time extension that effect on the delay of capital flows and development.

\section{Position of Power of Attorney to Charge Mortgage Rights in a Collateral Legal System}

The authorizing institution is indeed important in the life of a complex society at the present time, to facilitate someone who is unable to handle his legal transaction due to limited time, physical and socio-economic condition, etc. BW that regulates the lastgeving as a Dutch legal product legacy, based on the concordance principles, is applicable as a positive law in Indonesia. The term "lastgeving" referred to in Article $1792 \mathrm{BW}$, translated as "to grant power"' by R Subekti and R Tjitrosudibio, namely: to grant power of attorney is an agreement between the principal to someone else as an agent/attorney to act on his behalf. ${ }^{1}$

The word "agreement" indicates giving the power is a the concept of engagement (lastgeving), where the provisions of agreement validity and fundamental legal principles, namely the principle of consensualism, the principle of freedom of contract and the principle of binding power, apply to the power of attorney agreement. The word "for and on behalf of" is interpreted that in the agreement of the power of attorney, always grant someone else a power as representative, which effect on lastgeving provisions resulting power transfer (volmacht). ${ }^{2}$ Granting power and representation has 2 (two) different meanings in each legal relationship. Achmad Ichsan said that there are 3 (three) legal conditions relating to the legal relationship of power of attorney and authority to represent, namely (a) power of attorney along with representative authority, which caused the emergence of representation based on agreements (lastgeving and volmacht); (b) power of attorney without representation, does not cause representation (lastgeving) and (c) authority to represent without granting power (volmacht). ${ }^{3}$ According to Wirjono Prodjodikoro, as cited by Achmad Ichsan, said that the power of attorney without representation referred to in Article 1792 BW. Herlien Budiono said, in giving power of attorney it could also be given a representative authority, which result in representation based on agreement (contractuele vertegenwoordiging). ${ }^{5}$ Provisions regarding lastgeving as a power of attorney agreement also contain provisions concerning power (volmacht). The granting of power of attorney based on Article $1795 \mathrm{BW}$ states: "The granting of power of attorney can be carried out specifically, namely concerning only one particular interest or more, or in general, which includes all interests of the authorizer/ principal. $^{6}$

Special power of attorney is done between the principal and the agent/attorney to act on certain interest or more than the principal. While the general power of attorney means granting power is done by the principal to the agent. The substance of power granted is general of all the principal interest.

The SKMHT is a special power of attorney, does not contain the power to carry out other legal acts, but to grant Mortgage Rights. Because it is considered to have an important role in the guarantee of land rights and land related objects, the form is standardized in the standard form as stipulated in the Regulation of the Minister of Agrarian Affairs / Head of National Land Agency Number 3 of 1996 concerning the Form of SKMHT, Land Book of Mortgage Rights, and Mortgage Rights Certificate. The standard forms are made in such a way, containing important elements as required in UUHT. ${ }^{7}$ In addition, the validity period of SKMHT varies greatly, it can be valid for 1 (one) month, 3 (three) months even for certain credits. The Act stipulates that SKMHT can be valid until the validity period of the credit agreement. It will be more appropriate if certain credits are determined until the credit is completely settled.

Basically, in the case of a collateral, the mortgage can be carried out directly by the person who has the authority or through his power if the he is unable to do it himself. The use of SKMHT in the process of assigning new mortgages can be implemented when necessary. There are at least 2 (two) reasons for making and using SKMHT, are:

\footnotetext{
${ }^{1}$ R Subekti dan R Tjitrosudibio, Op. Cit., P. 98.

${ }^{2}$ R. Subeksi, Op. Cit., p. 23.

${ }^{3}$ Achmad Ichsan, Hukum Perdata IB, (Jakarta: Pembimbing Masa, 1969), p. 224

${ }^{4}$ Ibid., p. 38.

${ }^{5}$ Herlien Budiono, Kumpulan Tulisan Hukum Perdata, Di Bidang Kenotariatan, Buku Kesatu, (Bandung: Citra Aditya Bakti, 2012), p. 417

${ }^{6}$ and read the Provision of Article 1795 Burgerlijk Wetboek.

${ }^{7}$ See and read the attachment 2 of the Regulation of the Minister of Agrarian Affairs / Head of the National Land Agency Number 3 of 1996 concerning the Form of SKMHT, Book of Land Mortgage, and Certificate of Mortgage.
} 
1. The subjective requirements, namely:

a. The power giver/ principal cannot be present before a Notary / Land Deed Officer (PPAT) to make a Mortgage Right Certificate;

b. Long procedure of granting mortgage rights;

c. The cost of making mortgages rights is quite high;

d. Short-term loans;

e. Small Credit;

f. Reliable debtor.

2. Objective conditions, including:

b. Certificate has not been issued;

c. The transfer of the land title of mortgage rights principal has not been set;

d. Dividing/ merging of land has not been completed on behalf of the Mortgage rights grantor;

e. Roya / deletion has not been done.

In addition, the SKMHT contains 6 (six) principles, namely:

a. Date of signing of power of attorney;

b. The parties, i.e., the principal and the agent/ attorney;

c. The object of power, in the form of land rights, which will be granted a mortgage rights. In addition, the land area, location and boundaries are also included. This object of power includes the power to attend for providing information, hand the documents required, make and sign the APHT and other required documents, chose the domicile, give statement that the object of mortgage is owned by the principal which is free from dispute, confiscation and other loads, register the power of attorney, complete the requirements and provisions approved by the authorizer in the APHT;

d. Loading promises, either from the authorizer to the recipient of the power of attorney, or the promise from the power of attorney to the Underwriting Right Holder;

e. Witnesses, as well as;

f. Signatures of the parties.

Referring the above description, the existence of SKMHT is intended to guarantee the interests of creditors in charging collateral for land, and in the Micro Small and Medium Enterprises, the SKMHT is to protect the debtors from high costs. This balance show that the SKMHT exist to guarantee the sustainability of business on lands, in which the position is categorized as form of agreement or connector (overeenkomst tussen) analogized as a golden bridge of land-related business in Indonesia.

\subsection{Legal Construction of Power of Attorney for Mortgage Rights Regulation in the Collateral Legal System in Indonesia}

1. The SKMHT as A Part of Indonesian Collateral Legal system.

As stipulated in the provisions of Article 15 paragraph 5 of the UUHT jo of the Minister of Agrarian and Head of the National Land Agency Number 22 of 2017 concerning Determination of the Deadline for Use of SKMHT to Guarantee Repayment of Certain Loans, basically the SKMHT can be used as collateral for certain credit. 
However, the court verdicts stated that: Verdict Number 2006K / Pdt / 2011 states that SKMHT which is not an authentic deed, used as the basis for making APHT Number 122/2001 dated November 6, 2001, is illegal and illegitimate to guarantee Defendant I. The clause " is illegitimate to guarantee the Defendant I" indicates that the SKMHT can be used as a collateral.

In addition, the Minister of Agrarian and Spatial Planning / Head of the National Land Agency Number 22 of 2017 concerning the Determination of the Deadline for the Use of SKMHT to Guarantee the Payment of Certain Loans. The sentence "... the SKMHT is to guarantee repayment of certain loans" confirms that SKMHT is used as certain loans collateral. Therefore it is confusing weather the SKMHT is part of power in general or other form of collateral and agreements.

The SKMHT is a Power of Attorney given by the principal due to his disability to be present before the Land Deed Maker Officer. The principal is required to authorize other people as his proxy with the SKMHT in form of authentic deed. Based on this provision, the SKMHT is merely a Power of Attorney to replace legal actions to grant mortgage rights before the Land Deed Maker Officer.

In fact, the existence of Regulation of the Minister of Agrarian and Spatial Planning / Head of the National Land Agency Number 22 of 2017 concerning the Determination of the Deadline for Using SKMHT to Guarantee Repayment of Certain Loans shows that SKMHT is used as collateral for certain loans. As states in Decree Number 2006K / Pdt / 2011. that the SKMHT as collateral for certain loans is in line with the provisions of Article 15 Paragraph (2) of the UUHT which states that the power given or mortgage rights cannot be withdrawn or ended, except the power of attorney has been executed or the duration has been expired as referred to in Article 15 Paragraph (3) and (4) on the Act of Mortgage Rights (UUHT)

In addition, the provisions of Article 2 and Article 3 of the Minister of Agrarian and Spatial Planning / Head of the National Land Agency Number 22 of 2017 concerning Deadline for Using SKMHT to Guarantee the Repayment of Certain Loans, namely: Article 2 Regulation of Minister of Agrarian and Spatial Planning / Head of the National Land Agency Number 22 of 2017 concerning Determination of the Use of SKMHT Deadline to Guarantee Repayment of Specific Credit. The SKMHT to guarantee repayment of credit / financing / loans valid until the end of the principal agreement, as follows: Credit / Financing / Loans granted to customers of Micro and Small Businesses, which means personal productive business and/ or individual business entities; Credit / Financing / Loans intended for the procurement of housing, namely: Ownership or repair of core houses, simple houses or flats with a maximum land area of $200 \mathrm{~m}^{2}$ (two hundred square meters) and building less than $70 \mathrm{~m}^{2}$ (seventy square meters); and Ownership or repairs of Ready-to-Build lots with a land area of $54 \mathrm{~m}^{2}$ (fifty-four square meters) up to $72 \mathrm{~m}^{2}$ (seventy two square meters) and credit is given to finance the building.

Other productive credit / financing / loans with credit cap up to Rp. 200,000,000.00 (two hundred million rupiah). Article 3 of Minister of Agrarian and Spatial Planning / Head of National Land Agency Number 22 of 2017 concerning Determination of Deadline for Use of SKMHT to Guarantee Repayment of Certain Loans, the SKMHT is valid for 3 (three) months on land rights which are under management, with the following criteria: Productive Credit / Financing / loans for Micro / Small Business with a credit cap of Rp. 50,000,000 (fifty million rupiah) to Rp. 250,000,000.00 (two hundred fifty million rupiahs); Credit / Financing / Loans intended for the procurement of shop houses by Micro / Small Businesses with the maximum area of $200 \mathrm{~m}^{2}$ (two hundred square meters) and the widest building area of $70 \mathrm{~m}^{2}$ ( seventy square meters) with a credit / financing / loan cap less than Rp. 250,000,000.00 (two hundred fifty million rupiahs) guaranteed by the rights to the land financed by the procurement with the credit / financing / loan. The arrangement regarding the existence of this period indicates that the SKMHT is used as collateral in credit activities. It should consider all aspects related to the SKMHT as collateral, especially the position of the SKMHT.

Before the emergence of the SKMHT, the Power of Attorney to Execute hypothec is known in the collateral legal system. Most of the mortgage rights are built by referring to the basic principles and provisions of the Hypothec. After the application of Agrarian Basic Law and the Mortgage Rights Regulations, the Hypothec is not considered as a collateral for land and land relates objects. The definition of Hypothec is explained in the provisions of Article 1162 B.W. namely Hypothec is a material right for immovable property which is used as collateral in repayment of an agreement.

Before the regulation of Mortgage Rights existed, the imposition of all types of immovable property including land rights included in the hypothec collateral institution. In practice, the parties rarely take direct hypothec 
charges. ${ }^{1}$ The hypothec charges are made through the use of SKMH. ${ }^{2}$. Provisions of Article 1171 B.W. states that "Hypothec can only be given with authentic deeds, except in some cases which is expressly designated by law. The authorization to give a mortgage should also be made with an authentic deed ..."

Initially in the banking world, Hypothec is used as collateral institutions for loans given by debtors to creditors. By implementing hypothec on land used as collateral for credit by the debtor, the bank as a creditor will be protected from the risk of default by the debtor. Thus, basically, the SKMHT and SKMH are power of attorney that are used as collateral for credit. It means that both are material collateral. However, the due date on SKMHT cause a high cost economy.

Therefore, the high cost economy in the SKMHT can be minimized by making new adjustments in the SKMHT. The new designation can be done by taking the basic concept of SKMH into SKMHT, such the use of a power of attorney up to the credit period without any time limit which cause void of law if it is not continued to the APHT until a predetermined period of time.

\section{Returning the Aspiration Freedom of Contract Principle in the Decree of the SKMHT}

Freedom of contract is a reflection of the development of free market ideas pioneered by Adam Smith with his classical economic theory basing his thoughts on the teachings of natural law, the same matter also become the rationale for Jeremi Betham known as Utilitarianism. Utilitarianism and the classical economic theory of laisez faire are considered to be complementary and support the growth of individualistic liberal thinking. ${ }^{3}$

The principle of freedom of contract is a universal principle, meaning that it is adopted by law in all countries generally. ${ }^{4}$ According to the Indonesia Civil Law, freedom of contract is stipulated in the provisions of Article 1338 paragraph (1) B.W. which states that "all contracts (agreements) that are legally made apply as laws for the law maker". Subekti, by emphasizing the word" all ", it indicates that we are allowed to make any types of agreement that are binding. ${ }^{5}$

Whereas, according to Mariam Darus Badrul Zaman, "Freedom of contract is one of most important principles in the law of agreement. This freedom is an embodiment of free will, the emanation of human rights. Abdul Kadir Muhammad also stated that this Principle means that people may involve in any type of agreements, though it is not regulated by the law. This principle is often referred to as the "Freedom of making contract. ${ }^{6}$ The source of freedom of contract is the freedom of the individual which lies in the interest of the individual. Thus, the individual freedom gives him the freedom to make contract. The principle of freedom of contract according to Indonesian treaty law covers the scope of the following points: ${ }^{7}$

1. freedom to make or not to make an agreement;

2. freedom to choose the party to whom he wants to make an agreement;

3. freedom to determine or choose causal from the agreement (contract) to be made;

4. freedom to determine the object of the agreement;

5. freedom to determine the form of an agreement; and;

6. freedom to accept or deviate the provisions of the law which are optional (aanvullen,). ${ }^{8}$

The principle of freedom of contract in the agreement law is universal, meaning that it is also applicable to the other countries, have the same scope. The definition of freedom of contract in the civil law system originated

\footnotetext{
${ }^{1}$ Maria S.W. Sumardjono, Menyongsong Berlakunya UUHT Atas Tanah dan Benda-Benda yang Berkaitan dengan Tanah, Seminar paper in Yogyakarta 25 March 1996.

${ }^{2}$ Ibid.

${ }^{3}$ Sutan Remy Sjahdaeni, Kebebasan Berkontrak Dan Perlindungan Yang Seimbang Bagi Para Pihak Dalam Perjanjian Kredit Bank, (Jakarta: Institut Bankir Indonesia. 1993), P. 17

${ }^{4}$ Ibid.,

${ }^{5}$ Subekti, Hukum Perjanjian, 19th edition .(Jakarta: Intermasa, 2005) P. 47

${ }^{6}$ Muhammad Abdulkadir, Perjanjian Baku Dalam Praktek Perusahaan Perdagangan, (Bandung: Citra Aditya Bakti, 2010)

${ }^{7}$ Subekti. Loc Cit.

${ }^{8}$ Subekti. Loc Cit.
} 
and developed from the concept and development of engagement or obligatio, which was first used in the civil law tradition in Roman times by Emperor Justinian in Corpus Jurist Civilis in 533, institutionist part ${ }^{1}$ of Ancient Rome, the law grew and developed from the law that applies among families existed in the period, known as the family law. The two main fields regulated in this family law are regarding the inheritance of power (succession), and concerning ownership (property).

The initial agreement related to the SKMHT discussion stated that the SKMHT is a form of power agreement known as the principle of freedom of contract,. Furthermore, the existence of this SKMHT was a form of power agreement stipulated in Article 1320 B.W. that determine four conditions contained in each agreement. The fulfillment of these conditions, indicates an agreement is valid. The four conditions are:

1. Agree to make an agreement;

2. The ability to make agreements;

3. A certain matter;

4. A Lawful reason

As a part of the power agreement, SKMHT should fulfill the legal requirements of an agreement, it should also contain the principles of agreement law, one of which is the principle of freedom of contract. The existence of this principle is realized if the parties are given flexibility in determining the contents of the contracts based on the agreement of the parties. However in other provisions this form of SKMHT has been determined, the contents and duration have been set based on the Head of National Land Agency Regulation Number 8 of 2012 concerning Provisions for Implementing Government Regulation Number 24 of 1997 concerning Land Registration, which indicates that this SKMHT is a type of standard contract based on its implementation because the form has been determined based on the regulation, and both contents and the period as in the provisions of Article 15 paragraph 3, 4 and 5 of the Mortgage Rights Act. However, in fact, in the law which regulate both the position of Notary and the PPAT does not contain the provision regarding the form of the SKMHT that should be made by the Notary. It seems that the legal politics that arrange the regulation directing the Notary to follow the provisions of the Head of the National Land Agency of the Republic of Indonesia number 8 of 2012 concerning Provisions for the Implementation of Government Regulation Number 24 of 1997 on Land Registration.

1. Urgency of Synergy of the Freedom of Contract Principle and the Principles of Good Faith in the SKMHT Restructuring

The principle of Agreement Law is inseparable from each other, because its existence is independent and stands equal to each other, complete and complements each other in an agreement. The legal principle of the agreement works based on a function of check and balances system, so that it is able to reach the entire elements of the contract. $^{2}$

The freedom of contract principle is an initial requirement required at the process of making agreement with other parties. This principle stipulates that the parties can make any agreement as long as it follows the legislation, decency and public order. ${ }^{3}$ While other principles, such as the principle of pacta sun servada, as a binding principle, and state that an agreement made by the parties will act as a law for those who make it. Whereas, its implementation is based on the principle of good faith.

The principles of the agreement must be completely fulfilled because they connect one another and have a causal relationships that can create a legal certainty in an agreement formed, and if one of these principles is not implemented and / or not fulfilled, it will disable the agreement made, because these three principles are the subjective condition of an agreement.

\footnotetext{
${ }^{1}$ Gunawan Johanes, Kajian Ilmu Hukum Tentang Kebebasan Berkontrak, Dalam Butir-Butir Pemikiran dalam Hukum Commemorating 70 years of Pro. Dr. B. Arief Sidharta, S.H, (Bandung: Refika Aditama, 2011), p.259

${ }^{2}$ Fitria Hudaningrum, Hubungan antara Asas Kebebasan Berkontrak, Pacta Sun servada dan Itikad Baik, Journal Repertorium, Volume 1, No. 2, November 2014, p. 49

${ }^{3}$ See the provisions of Article 1337 Burgerlijk Wetboek
} 
In the history of the principle of freedom of contract and good faith, at its last development stage, the obligatio, in Roman law, contained both "duty" and "liability". The debtor is obliged to do whatever he has promised to do; if he fails to fulfill his obligations, he must be responsible for the contract. In the agreement or contract, and the obligation that arises is known as contractual obligations, while the responsibility risen by the contractual obligation is referred to as contractual liability.

Willingness as the basis of the contractual liability is possible to realize if the parties having the freedom to choose whether or not to bind themselves to a contract. If one party is in state of dependence whether or not to engage in a contract, he will definitely be unwilling to bind in an agreement when the contract finally happen. The freedom in this context is known as freedom of contract. ${ }^{1}$

There are five types of elements and conditions of freedom of contract in the civil law tradition, namely; Freedom to make or not to make an agreement; Freedom to choose which party to make an agreement with; Freedom to determine the contents of the agreement; Freedom to determine how to make an agreement. However, the implementation of freedom of contract is not an absolute freedom. In the Black's Law Dictionary the Freedom of contract or Liberty of Contract is interpreted as:

"The ability at will, to make or abstain from making, a binding obligatiaon enforced by the sanctions at the law. The right to contract abaut one"s affairs, including the right to make contract of employment, and to abstain the best terms one can as the result of private bargaining .It includes the corresponding right to accept a contract proposed. There is, however, no absolute freedom of contract. The government may regulate or forbid any contract reasonably calculated to affect injuriously public interest. Its means freedom from arbitrary or unreasonable restraint, not immunity from reasionable to safeguard public interest; or the right to make contract with competent person on a plane of relative parity or freedom of choice and wihin the limit allowed or not forbidden by law

This definition indicates that an absolute freedom is actually not acknowledged in an agreement or contract, but rather the freedom has limits which should not be exceeded in making the contract. ${ }^{2}$ In B.W. there are some restrictions by the articles which make the principle not absolute. Such Freedom to contract in the Article 1338 (1) of B.W. is restricted with the provision in Article 1320 (1) of B.W. regulating that a contract is not valid without any consensus or agreements between contracting parties. It show that, the agreement law is controlled by the Consensualism Principle. Provisions of Article 1320 paragraph 1 B.W. implies that the freedom of a party to determine the contents of the agreement is restricted by the other party's agreement. In other words the principle of freedom of contract is limited by the principle of consensualism. ${ }^{3}$

Provisions of Article 1320 paragraph (2) of B.W. concluded that people's freedom of contract is limited by the ability to make agreements. According to the Law, someone who is incapable of making an agreement, absolutely has no freedom to make contract. According to Article 1330 B.W., people who are immature and those who are under curatele do not have the ability to make an agreement. Then Article 1320 paragraph (4) B.W. jo Article 1337 B.W determines that the parties are not free to make agreements concerning causal prohibited by the law, or which is contrary to morality and public order. The agreement made must fulfill the halal causal. The agreement made with unlawful or prohibited causal according to the provisions of article 1335 B.W. are invalid. ${ }^{4}$

Provisions of Article 1332 B.W., Article 1333 B.W., and Article 1334 B.W. direct the freedom of the party to make an agreement as long as it concerns the object of the contract. According to these articles, there are limitation of the objects or goods brought to an agreement. Only goods having economic values that are allowed to use as agreement objects.

Article 1338 paragraph (3) B.W. determine the validity of the principle of "good faith" in implementing the contract. The application of this principle works since the agreement was made. It means, any contract made under bad faith cause the agreement to be invalid. Thus, the principle of good faith limits the freedom of contract for a party that should be based on good intentions. Even though the freedom of contract introduced by B.W., is

\footnotetext{
${ }^{1}$ Gunawan Johanes, Op.Cit., p. 261

${ }^{2}$ Ibid., p. 257

${ }^{3}$ Ibid., p. 48

${ }^{4}$ Ibid., p. 47
} 
also limited by B.W. Itself, its working power is very loose. The concession has caused inequality and injustice if the contracting parties do not have equal bargaining positions. ${ }^{1}$

\section{The SKMHT renewal in the Collateral Legal System}

The SKMHT is one form of special power granted in the context of imposing mortgage rights as a guarantee of repayment of loans in the process of bank credit. It is given in order to provide guarantees to creditors and debtors in the context of granting mortgage for land rights that have not complete the requirements for granting mortgage rights, for example, the land title certificates is still in the process of bonding, dividing, buying and selling, the roya/deletion and in the case of take over. The power to grant mortgages is present to facilitate the provision of credit in the above conditions to minimize obstacles in the provision of credit, and the circulation of economy continues so that it can improve the community's welfare.

Having important role in the process of granting credit and collateral, the SKMHT should be considered to provide legal certainty and legal protection for the parties so that the benefit of the power of attorney to charge mortgages is felt by the community, and is able to increase economic growth which impacts on the community welfare. To achieve this goal and to keep the balance of trading progress of world business, the improvement of the SKMHT concept should be considered that it will be applicable and lawful for parties. In addition, the legal gaps contained in the power of attorney to charge for mortgages and the effectiveness of SKMHT in accordance with the provisions of Article 15 paragraph 3 and 4 of the UUHT relating the period of mortgage use should be considered. Therefore the objectives of charging mortgage rights is obtained as well as to give profits for the parties concerned.

According to. Budi Harsono, charging Mortgage Rights is the authorization of land rights, containing the authority for creditors to manage any matters related to lands as collateral. The essence of mortgage definition is a rights to control over the lands and to sell the land if the debtor is reluctant.

These provisions indicate that there is a transition from the mortgage to the provisions of mortgage rights in lands collateral. According to Budi Harsono, mortgage rights is a merger of mortgage and creditverband institutions. ${ }^{2}$ The Mortgage rights has an important role in the renewal of collateral institution to protect parties interest in applying the collateral of mortgage. The existence of the SKMHT as media for mortgage rights is important in the implementation of collateral institutions of mortgage. Basically, the imposition of mortgage rights must be done by the principal or the interest parties. It does not imply that it is prohibited to give the power to someone else as stipulated in Article 15 paragraph $1^{3}$ of the UUHT that the term "obliged" should not be deviated. This word relates to the Notary Deed or the PPAT for charging mortgage rights to use the authentic deeds. However, the article explains that this power transfer should be done by the principal himself.

The explanation stating that "only if it is necessary" people may use the power of attorney to charge mortgage rights, it can cause uncertainty because the law does not state the conditions need the use of the SKMHT. This ambiguities of the SKMHT concept is the factor for renewal of SKMHT based on Article 15 of the Act of Mortgage Rights.

Only the amendment of the Act of Mortgage Rights that can regulate the provision related to the SKMHT, since it emerged from this Act stipulated in Article 15. This amendment will give legal certainty and protection for interested parties.

\section{The SKMHT as an Overseenkomst Tussen in the Collateral Legal System}

The granting of power as a unilateral legal action is the giving the authority to the agent/attorney to represent the principal's legal interests. Unilateral legal actions are not consideres as agreement that do not have any juridical binding force. ${ }^{4}$ It means that the power of attorney as a unilateral legal action only give representative authority,

\footnotetext{
${ }^{1}$ Ibid., p. 49

${ }^{2}$ Djuhaendah Hasan, Lembaga Jaminan Kebendaan Bagi Tanah Dan Benda Lain Yang Melekat Pada Tanah Dalam Konsepsi Penerapan Asas Pemisahan Horizontal. (Jakarta, nuansa madani, 2011), p. 275

${ }^{3}$ Article 15 paragraph 1 of Mortgage Rights Act states that the power of attorney to charge mortgages must be made with a notary deed or PPAT deed and fulfill the following prerequisites: a). Does not contain the power to carry out other legal actions rather than impose mortgage rights; b). does not contain the power of substitution; c). clearly state the object of mortgage, the amount of debt and the name and identity of the creditor, the name and identity of the debtor if the debtor is not the giver of the mortgage.

${ }^{4}$ Pieter E Latumeten, Reposisi Pemberian Kuasa dalam Konsep Volmacht dan Lastgeving Berdasarkan Cita Hukum Pancasila, journal of law and development 47 No. 1, 2017: 1-37,p. 29.
} 
thus the authorizer can revoke and terminate his power unilaterally. In addition, authorization can be done as a two-party agreement (reciprocal legal action) made of agreements between the two involving parties i.e., the principal and the agent/attorney. This agreement is not followed by concrete actions which does not impact on the emergence of juridical binding force. The absence of concrete actions in the granting of this power of attorney, the authorizer/principal is not liable to represent his power to the agent/ attorney. Therefore, the principle is able to terminate the power of attorney unilaterally. ${ }^{1}$

It is different from the power of attorney granted for the interest of the principal and the attorney. The principal is known as an accessoir of mutual agreement. In practice, both accessoir and agent have their respective achievement to obtain. The power of attorney has a juridical binding power as long as the reciprocal agreements is ongoing. But, if the agreement is over, the power granted will also end. As well as the achievement obtain by both parties. If they do not fulfill the existing conditions, then the legal action is void by law.

Regarding the formulation process, the SKMHT is unique. If the SKMH is part of mortgage, the SKMHT is available under certain conditions that the authorizer/ principal is not able to be present before the Land Deed Officials to sign the APHT.

Based on the above elaboration, the SKMHT is known as as a form of agreement between the agreement of SKMHT and APHT, as a part of special power of attorney which is a prerequisite for banking credits. On the other hand, the SKMHT is an agreement used as a temporary collateral or until the due date of the credits as stipulated in Regulation of Minister of Agrarian and Spatial Planning / Head of the National Land Agency Number 22 of 2017 concerning Determination of the Deadline for Use of SKMHT to Guarantee Repayment of Certain Loans.

\section{Conclusion}

Based on the above examination, it can be concluded that:

1. The SKMHT is part of the power of attorney agreement. It is made in the form of a deed and an agreement. It is based on the power of attorney in general, which can be reviewed in the elements and general terms of power of attorney stipulated in Article 1792 BW which have similarities with the SKMHT. The difference only emphasis that the form of SKMHT is only intended for the application of mortgages. The SKMHT emerging from an agreement must be based on the principle of freedom of contract. SKMHT as part of the power of attorney agreement is then used as collateral for credit which can be seen in the provisions of Article 15 Paragraph (5) of UUHT, which is further emphasized by the ratification of the Minister of Agrarian and Spatial Planning / Head of the National Land Agency of the Republic of Indonesia Number 4 of 1996 concerning the Determination of the Deadline for Use of SKMHT. which was later amended by the Minister of Agrarian and Spatial Planning / Head of the National Land Agency of the Republic of Indonesia Number 22 of 2017 concerning Determination of the Deadline for the Use of SKMHT to Guarantee the Payment of Certain Loans.

2. In all crediting activities, principally the SKMHT acted as an agreement between the process of credit to the application of mortgage. This function makes the SKMHT as a bridge for two legal actions of one entity which cannot be carried out simultaneously. This power made for special purpose and regulation which cannot be replaced by any other types of power. It refers to the provision of Article 15 of the UUHT. As an irreplaceable connector, SKMHT should be considered to have a special position in the collateral legal system, i.e., it is analogous to the golden bridge.

3. The SKMHT as part of the agreement law, namely the power of attorney agreement, automatically all the principles of the agreement must be covered by the SKMHT. Basically, the principles must be entirely applied and cannot be separated, though these principles are independent and have equal position. However, the disability to fulfill these principles causes broken will. Thus, any form of agreement qualified as having broken will are null and void. The legal renewal of the SKMHT concept has a very important role as a medium for mortgage rights, and serves as a collateral for certain loans. the SKMHT as a form of

\footnotetext{
${ }^{1}$ Ibid., p. 31.
} 
power that relates to the provisions of Article $1792 \mathrm{BW}$, can be categorized as a quasi-collateral, because it can guarantee credits to its end as stipulated in the Minister of Agrarian and Spatial Regulation / Head of the National Land Agency of the Republic of Indonesia Number 222017 concerning Determination of the Deadline for the Use of SKMHT to Guarantee the Payment of Certain Loans. Besides that, the SKMHT can also be categorized as an overseenkomst tussen agreement referring to its position in the collateral legal system in Indonesia..

\section{Suggestion}

Based on the above conclusions, it shows that there are still normative weaknesses on the regulation of SKMHT, therefore the authors suggest as follows:

1. Lawmakers must improve Article 15 Paragraph (2) Paragraph (3) Paragraph (4) Paragraph (5) of Act of Mortgage Rights;

2. The lawmaker must reinforce the limitations on the clause "SKMHT is made if necessary" of the General Explanation of Mortgage Rights Law due to its vague meaning;

3. The lawmaker should amendment Article 15 Paragraph (2) Paragraph (3) Paragraph (4) Paragraph (5) of Mortgage Rights and PMA Laws concerning Determination of the Deadline for the Use of SKMHT to Guarantee Repayment of Certain Loans.

\section{References}

\section{Books}

J. Satrio. 1998. Hukum Jaminan, Hak Jaminan Kebendaan, Hak Tanggungan Buku 2. Bandung: Citra Aditya Bakti.

Philipus M. Hadjon dan Tatiek Sri Djatminiati. 2014. Argumentasi Hukum, Sixth edition. Yogyakarta: Gadjah Mada University Press.

Peter Mahmud Marzuki. 2010. Penelitian Hukum. Jakarta: Kencana Prenada.

Purawahid Patrik dan Kashadi. 2009. Hukum Jaminan, (Semarang: Badan Penerbit Universitas Diponegoro.

Achmad Ichsan. 1969. Hukum Perdata IB. Jakarta: Pembimbing Masa.

Herlien Budiono. 2012. Kumpulan Tulisan Hukum Perdata, Di Bidang Kenotariatan, Buku Kesatu. Bandung: Citra Aditya Bakti.

Salim HS. 2017. Perkembangan Hukum Jaminan Di Indonesia. Jakarta: Raja Grafindo.

Sutan Remy Sjahdaeni. 1993. Kebebasan Berkontrak Dan Perlindungan Yang Seimbang Bagi Para Pihak Dalam Perjanjian Kredit Bank. Jakarta: Institut Bankir Indonesia.

Muhammad Abdulkadir. 2010. Perjanjian Baku Dalam Praktek Perusahaan Perdagangan. Bandung: Citra Aditya Bakti.

Gunawan Johanes. Kajian Ilmu Hukum Tentang Kebebasan Berkontrak, Dalam Butir-Butir Pemikiran dalam Hukum, Memperngati 70 Tahun Prof. Dr. B. Arief Sidharta, S.H. Bandung: Refika Aditama.

Subekti. 2005. Hukum Perjanjian, 19th Edition.Jakarta: Intermasa.

Djuhaendah Hasan. 2011. Lembaga Jaminan Kebendaan Bagi Tanah Dan Benda Lain Yang Melekat Pada Tanah Dalam Konsepsi Penerapan Asas Pemisahan Horizontal. Jakarta, nuansa madani.

\section{Journals}


Okky Ditya Argo Putra, Prinsip Prinsip Hukum Jaminan dalam Undang-Undang Nomor 4 Tahun 1996 tentang Hak Tanggungan Atas Tanah beserta Benda-benda yang Berkaitan dengan Tanah, Jurnal Reportorium 1st Edition, Januari-Juli, 2014

Pieter E Latumeten, Reposisi Pemberian Kuasa dalam Konsep Volmacht dan Lastgeving Berdasarkan Cita Hukum Pancasila, Jurnal Hukum \& Pembangunan 47 No. 1, 2017

Fitria Hudaningrum, Hubungan antara Asas Kebebasan Berkontrak, Pacta Sun servada dan Itikad Baik, Jurnal Repertorium, Volume 1, No. 2, November 2014

Made Oka Cahyadi Wiguna, SKMHT dan Pengaruhnya Terhadap Pemenuhan Asas Publisitas dalam Proses Pemberian Hak Tanggungan, A Paper of Universitas Pendidikan Nasional, Denpasar, 2015.

Maria S.W. Sumardjono, Menyongsong Berlakunya UUHT Atas Tanah dan Benda-Benda yang Berkaitan dengan Tanah, A seminar paper in Yogyakarta March 25th, 1996

\section{Legislations}

\section{Burgelijk Wetbook}

Act Number 5 of 1960 concerning Basic Agrarian Principles. (State Gazette of the Republic of Indonesia of 1960 Number 104, Supplement to the State Gazette of the Republic of Indonesia Number 2043).

Act Number 4 of 1996 concerning the Mortgage Rights on Land and Land Related Objects. (State Gazette of the Republic of Indonesia of 1996 Number 42, Supplement to the State Gazette of the Republic of Indonesia Number 3632).

Act Number 10 of 1998 concerning Amendments to Law Number 7 of 1992 concerning Banking

Regulation of the Minister of Agrarian Affairs / Head of the National Land Agency Number 3 of 1996 concerning Forms of Power of Attorney for Mortgage Rights, Book of Land for Mortgage Rights, and Certificate of Mortgage Rights.

Regulation of the Minister of Agrarian Affairs and Spatial Planning / Head of the National Land Agency of the Republic of Indonesia Number 4 of 1996 concerning Determination of the Deadline for Use of Power of Attorney for Mortgage Rights to Guarantee the Repayment of Certain Loans (Official Gazette of the Republic of Indonesia Year 1996 Number 09)

Regulation of the Minister of Agrarian Affairs and Spatial Planning / Head of the National Land Agency of the Republic of Indonesia Number 22 Year 2017 concerning Determination of Deadline for Use of Power of Attorney for Mortgage Rights to Guarantee Repayment of Certain Loans (Official Gazette of the Republic of Indonesia 2018 Number 113). 